\title{
KELAYAKAN MODUL IPA SMP/MTS BERBASIS PROBLEM BASED LEARNING PADA MATERI SUHU DAN PEMUAIAN
}

\author{
Wahyu Tri Sajiwo ${ }^{1}$, Sarwanto $^{2}$, Ashadi ${ }^{3}$ \\ ${ }^{1}$ Program Studi Magister Pendidikan Sains FKIP Universitas Sebelas Maret \\ Surakarta, 57126, Indonesia \\ wahyutris@student.uns.ac.id \\ ${ }^{2}$ Program Studi Magister Pendidikan Sains FKIP Universitas Sebelas Maret \\ Surakarta, 57126, Indonesia \\ sarwanto_fkip@staff.uns.ac.id \\ ${ }^{3}$ Program Studi Magister Pendidikan Sains FKIP Universitas Sebelas Maret \\ Surakarta, 57126, Indonesia \\ ashadi.uns.ac.id@staff.uns.ac.id
}

\begin{abstract}
Abstrak
Pendidikan sains adalah pendidikan yang memiliki kontribusi dalam peningkatan kualitas pendidikan khususnya mata pelajaran IPA. Pembelajaran IPA di SMP/MTs masih banyak yang menggunakan metode konvensional, belum berbasis masalah dan belum digunakan untuk meningkatkan berpikir kritis siswa. Penelitian ini bertujuan untuk: 1) menganalisis karakteristik modul IPA berbasis Problem Based Learning yang dapat meningkatkan kemampuan berpikir kritis siswa pada materi suhu dan pemuaian; 2) menganalisis kelayakan modul IPA berbasis Problem Based Learning yang dapat meningkatkan kemampuan berpikir kritis siswa pada materi suhu dan pemuaian; 3) menganalisis efektivitas modul IPA berbasis Problem Based Learning yang dapat meningkatkan kemampuan berpikir kritis siswa pada materi suhu dan pemuaian. Pengembangan modul berbasis Problem Based Learning ini merupakan penelitian Research and Development (R\&D) dengan menggunakan 4-D Model Thiagarajan yang terdiri dari 4 tahap yaitu: tahap pendefinisian (define), tahap perancangan (design), tahap pengembangan (develop), dan tahap penyebaran (disseminate). Modul divalidasi oleh 3 dosen ahli (ahli materi, ahli bahasa dan ahli media), 2 reviewer dan 2 peer reviewer. Modul IPA berbasis Problem Based Learning yang dikembangkan diujicoba terbatas pada 10 orang siswa Kelas VII A. Berdasarkan hasil penelitian dan pengembangan disimpulkan bahwa: 1) karakteristik modul IPA yang dikembangkan memuat tahapan Problem Based Learning pada setiap kegiatan belajar disertai dengan komponen indikator kemampuan berpikir kritis; 2) modul dikategorikan layak digunakan berdasarkan hasil validasi dan dianalisis menggunakan cut off score dengan persentase keidealan 92,0\%, hasil respon dari siswa modul layak digunakan $(85,7 \%)$, dan hasil respons guru dalam tahap penyebaran modul layak digunakan $(88,2 \%)$.
\end{abstract}

Kata Kunci: modul, problem based learning, berpikir kritis, suhu, pemuaian

\section{Pendahuluan}

IPA merupakan ilmu pengetahuan yang mengkaji berbagai prinsip-prinsip fundamental dari alam semesta. Hal ini memberi tantangan tersendiri baik bagi guru maupun siswa untuk mempelajari, memaknai, hingga kemungkinan mengaplikasikannya dalam kehidupan. Salah satu problematika dalam disiplin ilmu ini adalah pembahasaan objek-objek yang ditinjau sangat kompleks dan pada perilaku tertentu sulit diungkapkan dengan bahasa sehari-hari. Akibatnya adalah IPA diinterpretasikan sebagai suatu mata pelajaran yang rumit, tidak hanya bagi siswa tetapi juga bagi masyarakat awam. Bransford dan Donovan (2005) memberikan 
pandangan terhadap gejala ini bahwa untuk memahami IPA, maka harus mengerti istilah-istilah ilmiah dan mengetahui penemuan-penemuan penting di masa lalu. Anggapan ini memberi arti bahwa sains layaknya doktrin kuat untuk menerima segala fakta-fakta tanpa memahami makna di baliknya.

Kurikulum 2013 pada mata pelajaran IPA menjelaskan bahwa fisika merupakan salah satu cabang IPA yang mendasari perkembangan teknologi maju dan konsep hidup harmonis dengan alam. Hal ini dapat dilihat dari pesatnya perkembangan di bidang teknologi informasi dan komunikasi yang dipicu oleh penemuan di bidang fisika material melalui penemuan piranti mikroelektronika yang mampu memuat banyak informasi dengan ukuran sangat kecil. Namun pada kenyataanya, kemampuan siswa untuk mengaplikasikan ilmu IPA dalam kehidupan masih kurang. Telah dikemukakan beberapa pendekatan pembelajaran yang mengaitkan antara suatu bidang yang dikaji dengan masalah aktual sehingga dari pengetahuan yang diperoleh dapat dimanfaatkan dalam kehidupan seharihari siswa.

Problem Based Learning (PBL)
adalah model pembelajaran yang
mengarahkan siswa belajar melalui
permasalahan-permasalahan praktis
yang berhubungan dengan kehidupan
nyata, selanjutnya siswa diarahkan
untuk menyelesaikan permasalahan
tersebut melalui serangkaian
pembelajaran yang sistematis, agar siswa mampu menemukan solusi dari permasalahan atau dapat memecahkan permasalahan tersebut serta mampu mengambil kesimpulan berdasarkan pemahaman mereka (Rubi, 2012). PBL memiliki beberapa kelebihan di antaranya: mampu membuat siswa lebih aktif, meningkatkan kemampuan siswa untuk memecahkan permasalahan dalam kehidupan sehari-hari, menimbulkan ide-ide baru, meningkatkan keakraban dan kerjasama antar siswa serta menjadikan pendidikan di sekolah menjadi lebih relevan dengan kehidupan sehari-hari (Trianto, 2009).

Dalam pembelajaran modern, kemampuan berpikir kritis merupakan suatu hal yang penting. Semua guru diharapkan tertarik untuk memberikan kemampuan berpikir kritis ini kepada siswanya (Schafersman, 1991). Berpikir kritis merupakan kegiatan menggunakan argumen dan menilai kepercayaan dengan akurat. Kemampuan berpikir kritis dapat diajarkan melalui sebuah pendidikan agar mampu menilai dengan akurat, dan berargumentasi dengan baik. Pendidikan merupakan substansi yang penting dalam mewujudkan manusia yang handal dan mandiri untuk memecahkan masalah secara kritis.

Modul adalah salah satu bentuk bahan ajar yang dikemas secara utuh dan sistematis, di dalamnya memuat seperangkat pengalaman belajar yang terencana, dan didesain untuk membantu siswa menguasai tujuan belajar yang spesifik (Daryanto, 2013). Pengembangan modul penting dilakukan guru untuk meningkatkan kualitas dan efisiensi pembelajaran. Pengembangan modul memiliki komponen-komponen tertentu yang harus diperhatikan oleh guru agar dapat dihasilkan modul yang memiliki peran penting baik bagi guru maupun siswa. Dengan adanya modul yang sesuai dengan karakteristik siswa dan tujuan pembelajaran maka tingkat pemahaman siswa terhadap pelajaran akan meningkat.

Pembelajaran PBL yang disertai dengan percobaan dapat meningkatkan kemampuan berpikir kritis, menumbuhkan inisiatif siswa dalam berkinerja, siswa terlibat aktif dalam mengumpulkan fakta, informasi, atau data yang diperlukan melalui percobaan yang dilakukannya, serta dapat mengembangkan hubungan 
interpersonal dalam bekerja kelompok. Sehingga pembelajaran bermakna ini akan dapat meningkatkan aktivitas siswa dalam belajar serta tercapai prestasi belajar pada kompetensi sikap, pengetahuan, dan keterampilan yang lebih baik.

Berdasarkan uraian latar belakang di atas, maka penelitian ini bertujuan untuk: 1) menganalisis karakteristik modul IPA berbasis Problem Based Learning yang dapat meningkatkan kemampuan berpikir kritis siswa pada materi suhu dan pemuaian; 2) menganalisis kelayakan modul IPA berbasis Problem Based Learning yang dapat meningkatkan kemampuan berpikir kritis siswa pada materi suhu dan pemuaian.

\section{Metode Penelitian}

Penelitian ini merupakan penelitian dan pengembangan (research and development/R\&D). Model yang digunakan sebagai dasar untuk mengembangkan modul IPA berbasis PBL pada materi suhu dan pemuaian merupakan hasil adaptasi model 4-D (four-D model) yang dikemukakan oleh Thiagarajan (1974: 5). Prosedur pengembangan modul IPA berbasis PBL menggunakan model 4-D yang meliputi define, design, development, dan disseminate.

Teknik pengumpulan data dalam penelitian ini menggunakan: (1) angket untuk analisis kebutuhan; (2) lembar validasi untuk mendapatkan penilaian serta saran terhadap desain produk awal

Produk yang dikembangkan berupa modul IPA berbasis PBL yang divalidasi oleh validator yang terdiri dari tiga dosen ahli, dua guru, dan dua peer reviewer. Subyek yang diteliti yaitu siswa kelas VII G SMP N 2 Selogiri tahun pelajaran 2016/2017. Sampel pada uji coba terbatas sebanyak 10 siswa kelas VII A. Uji luas dilakukan pada kelas eksperimen dengan jumlah siswa sebanyak 21 orang. Hasil penilaian yang digunakan adalah hasil validasi oleh ahli media, ahli materi, ahli bahasa, guru, dan peer reviewer. Jika skor rata-rata hasil penilaian lebih besar dari skor batas bawah, maka dapat disimpulkan bahwa layak untuk digunakan.

\section{Hasil Penelitian dan Pembahasan}

\section{A. Hasil Penelitian Pengembangan}

Penelitian yang telah dilakukan menghasilkan produk berupa Modul IPA Berbasis PBL pada materi suhu dan pemuaian SMP Kelas VII Semester II. Penelitian menggunakan Model 4-D oleh Thiagarajan (1974) yang terdiri dari empat tahap kegiatan yaitu pendefinisian (define), perancangan (design), pengembangan (develop), dan penyebaran (disseminate). Penjabaran hasil penelitian dari setiap tahap kegiatan yang dilakukan adalah sebagai berikut:

\section{Tahap Pendefinisian (Define)}

Tahap pendefinisian dilakukan untuk mengidentifikasi masalah-masalah yang ada dalam pembelajaran dan menjadi dasar untuk merancang produk penelitian. Pada tahap ini dilakukan penyebaran angket analisis kebutuhan dan wawancara di SMP Negeri 2 Selogiri. Penyebaran angket kebutuhan siswa diberikan kepada 22 siswa Kelas VII G. Angket kebutuhan guru dan wawancara dilakukan kepada guru IPA SMP Negeri 2 Selogiri terhadap pembelajaran IPA.

Hasil observasi di SMP Negeri 2 Selogiri dalam tahap analisis kebutuhan diperoleh kesimpulan bahwa: (1) hampir seluruh siswa yaitu sebesar $91 \%$ menyatakan kesulitan mempelajari materi suhu dan pemuaian yaitu pada konsep konversi skala suhu termometer, dan menghitung pertambahan pemuaian pada zat padat, cair, dan gas yang dipanaskan; (2) tidak semua praktikum sudah dilengkapi buku panduan yaitu 
hanya sebesar $40 \%$. Buku panduan praktikum yang sudah ada yaitu pada materi optik, listrik, dan magnet, sementara pada materi suhu dan pemuaian tidak terdapat buku panduan praktikum; (3) pembelajaran dengan percobaan masih jarang dilakukan, yaitu hanya sebanyak $60 \%$ dari seluruh materi dalam satu semester sehingga pemahaman siswa mengenai materi kurang baik; (4) buku pegangan yang disediakan sekolah belum sepenuhnya membantu siswa dalam memahami materi IPA, karena sebanyak $77 \%$ siswa mengalami kesulitan dalam memahami materi dari buku pegangan; (5) guru tidak menggunakan bahan ajar yang dapat meningkatkan berpikir kritis siswa.

Hasil analisis materi ditujukan untuk menentukan Kompetensi Inti, Kompetensi Dasar, dan materi pembelajaran yang memungkinkan untuk dipilih sebagai acuan pengembangan perangkat pembelajaran. Materi yang dipilih pada penelitian ini adalah materi suhu dan pemuaian. Pada materi ini menunjukkan bahwa rata-rata nilai ulangan harian siswa kelas VII G SMP Negeri 2 Selogiri adalah 67, di bawah nilai KKM yang ditetapkan yaitu 75 .

\section{Tahap Perancangan (Design)}

Tahap perancangan dilakukan berdasarkan hasil analisis kebutuhan yang telah diberikan kepada siswa dan guru pada tahap pendefinisian. Dari hasil analisis kebutuhan dapat diketahui spesifikasi produk yang akan dikembangkan. Tahap perancangan meliputi analisis konsep, urutan penyajian pembelajaran, pemilihan media, pemilihan format, rancangan awal, dan penyusunan instrumen.

Produk yang akan dihasilkan berupa modul berbasis PBL pada materi suhu dan pemuaian untuk meningkatkan berpikir kritis siswa. Modul yang dikembangkan dilengkapi dengan petunjuk penggunaan modul, pendahuluan, tujuan serta indikator yang ingin dicapai, materi, langkah-langkah atau prosedur melaksanakan percobaan yang dilengkapi dengan penjelasan tentang alat dan bahan serta penggunaan alat yang disajikan, kolom hasil untuk menuliskan hasil dari percobaan, lembar diskusi untuk menjawab analisis berdasarkan percobaan, petunjuk untuk melakukan presentasi, penerapan materi, latihan soal serta pembahasan, evaluasi dan glosarium.

\section{Tahap (Develop) \\ Pengembangan}

Tahap Develop dilakukan tahapan validasi oleh ahli, guru, dan peer reviewer kemudian uji coba terbatas dan uji luas. Hasil validasi dari keseluruhan kemudian dihitung menggunakan metode cut off score (Winnie, 2009) untuk mengetahui kelayakan modul IPA berbasis PBL yang telah dikembangkan. Tabel 1. Hasil Analisis Validasi Modul

\begin{tabular}{lll}
\hline \multirow{2}{*}{ No } & Validator & $\begin{array}{l}\text { Persentase } \\
\text { Keidealan }(\%)\end{array}$ \\
\hline 1 & Ahli Materi & 88,2 \\
2 & Ahli Bahasa & 89,3 \\
3 & Ahli Media & 94,0 \\
4 & Peer Reviewer I & 88,6 \\
5 & Peer Reviewer II & 94,3 \\
6 & Reviewer I & 94,3 \\
7 & Reviewer II & 95,4 \\
\hline Nilai Maksimum & 95,4 \\
Nilai Minimum & 88,2 \\
Natural Cut Off Score & 91,8 \\
Nilai Rata-Rata & 92,0 \\
Keterangan & Layak \\
\hline
\end{tabular}

Hasil dari validasi materi diperoleh kategori sangat baik dengan persentase keidealan 88,2\%. Kesimpulan dari validator ahli materi adalah valid dengan revisi sesuai saran. Hasil dari validasi bahasa diperoleh kategori sangat baik dengan persentase keidealan 89,3\%. Kesimpulan dari validator ahli bahasa adalah valid. Hasil dari validasi media diperoleh kategori sangat baik dengan persentase keidealan 94\%. Kesimpulan dari validator ahli media adalah valid. Hasil dari penilaian 
reviewer diperoleh kategori sangat baik dengan persentase keidealan $94,8 \%$. Hasil dari penilaian peer reviewer diperoleh kategori sangat baik dengan persentase keidealan 91,4\%. Hasil validasi ahli, peer reviewer dan reviewer terhadap modul yang telah dikembangkan secara keseluruhan menunjukkan bahwa modul layak digunakan.

Berdasarkan penilaian guru (reviewer) yang telah dilakukan, terdapat beberapa kritik dan saran. Adapun kritik dan saran disampaikan pada Tabel 2.

Tabel 2. Kritik dan Saran Reviewer

\begin{tabular}{lcl}
\hline Guru 1 & Guru 2 \\
\hline Pada & rangkuman & Penulisan halaman 2 \\
halaman & 58 poin 4 & menimbulkan persepsi \\
terdapat kesalahan. & yang berbeda bagi \\
Besar pertambahan & pembaca, pada kalimat \\
panjang & benda & "suhu capai" \\
berbanding $\quad$ lurus & \\
dengan & besar & \\
koefisien muainya & \\
\hline
\end{tabular}

Berdasarkan dari penilaian teman sejawat (peer reviewer), terdapat beberapa kritik dan saran. Adapun kritik dan saran disajikan dalam Tabel 3.

Tabel 3. Kritik dan Saran Teman Sejahwat

\begin{tabular}{lll}
\hline Teman 1 & Teman 2 \\
\hline $\begin{array}{l}\text { Perbaiki kalimat } \\
\text { dalam penulisan kata ganti orang } \\
\text { praktikum prosedur }\end{array}$ & $\begin{array}{l}\text { (kamu, kalian) sesuai } \\
\text { Perbaiki gambar } \\
\text { (resolusi dan skala) }\end{array}$ & $\begin{array}{l}\text { Penulisan "di" dengan kata } \\
\text { tempat / bukan tempat } \\
\text { dibedakan }\end{array}$ \\
\hline
\end{tabular}

Modul IPA berbasis PBL yang telah divalidasi oleh validator ahli dan dilakukan perbaikan sesuai saran validator kemudian diujicobakan pada uji coba terbatas. Tujuan dari uji coba terbatas adalah untuk mengetahui keterbacaan modul oleh siswa. Modul diujicobakan kepada 10 orang siswa kelas VII A SMP Negeri 2 Selogiri yang telah mendapat materi suhu dan pemuaian sebelumnya. Setelah mempelajari modul, kemudian siswa mengisi angket respon siswa serta memberikan saran dan komentar pada lembar penilaian yang telah disediakan.
Hasil angket respon siswa disajikan dalam tabel 4.

Tabel 4.. Hasil Angket Respon Siswa

\begin{tabular}{lll}
\hline No. & Siswa & Persentase Keidealan $(\%)$ \\
\hline 1. & Siswa 1 & 76,1 \\
2. & Siswa 2 & 85,2 \\
3. & Siswa 3 & 86,4 \\
4. & Siswa 4 & 88,6 \\
5. & Siswa 5 & 78,4 \\
6. & Siswa 6 & 90,9 \\
7. $\quad$ Siswa 7 & 93,2 \\
8. $\quad$ Siswa 8 & 78,4 \\
9. Siswa 9 & 92,0 \\
10. $\quad$ Siswa 10 & 87,5 \\
\hline Nilai & Maksimum & 93,2 \\
Nilai & Minimum & 76,1 \\
Natural Cut $\quad$ Off & 84,6 \\
Score & 85,7 \\
Nilai Rata-rata & Layak \\
\multicolumn{2}{l}{ Keterangan } &
\end{tabular}

Hasil dari uji coba terbatas adalah jawaban siswa atas kegiatan percobaan dan pertanyaan-pertanyaan yang ada dalam modul serta penilaian pada lembar angket keterbacaan modul. Hasil jawaban siswa selanjutnya dianalisis dan dicocokkan dengan kunci jawaban. Perbaikan dilakukan apabila terdapat kesalahan dan ketidakjelasan yang membuat siswa kurang memahami maksud dari modul. Tingkat keterbacaan modul pada uji terbatas untuk kegiatan belajar 1 yaitu $75 \%$, sementara untuk kegiatan belajar 2 yaitu $80 \%$. Pada kegiatan belajar 1 keterbacaan yang diperoleh lebih kecil dikarenakan ada beberapa bagian yang masih perlu diperbaiki.

\section{B. Pembahasan}

\section{Karakteristik Modul IPA Berbasis PBL untuk Meningkatkan Berpikir Kritis Siswa}

Modul IPA berbasis PBL (Problem Based Learning) untuk meningkatkan berpikir kritis siswa pada materi suhu dan pemuaian dikembangkan berdasarkan prosedur pengembangan Model 4-D (four D model) oleh Thiagarajan (1974). Prosedur pengembangan ini terdiri dari empat 
tahap kegiatan yaitu pendefinisian (define), perancangan (design), pengembangan (develop), dan penyebaran (disseminate). Modul berbasis PBL untuk meningkatkan berpikir kritis siswa pada materi suhu dan pemuaian dikemas dalam bentuk cetak. Modul ini memuat lima tahapan pembelajaran PBL untuk meningkatkan berpikir kritis siswa yang ditunjukkan dengan ikon tertentu. Tahapan pembelajaran PBL muncul pada setiap komponen kegiatan dalam modul. Tahapan PBL orientasi siswa pada masalah, dan tahapan mengorganisasikan siswa untuk belajar, muncul dalam kegiatan pada fenomena yaitu bagian Orientasi Masalah, dan Organisasi Belajar. Tahapan PBL membimbing penyelidikan individu maupun kelompok, muncul pada bagian Kegiatan Penyelidikan. Tahapan PBL mengembangkan dan menyajikan hasil karya, muncul dalam bagian Pertanyaan Diskusi. Tahapan PBL menganalisis dan mengevaluasi proses pemecahan masalah, muncul pada bagian Refleksi.

Dari penelitian yang dilakukan Adnyana (2012) dapat disimpulkan bahwa melalui pembelajaran menggunakan model PBL dalam penelitian ini terjadi peningkatan kualitas pembelajaran, berupa terdapatnya peningkatan nilai hasil belajar siswa dan secara langsung terdapat peningkatan pemahaman terhadap materi yang diberikan. Aspek berpikir kritis yang ditingkatkan sesuai dengan pendapat Ennis yaitu mengidentifikasi alasan yang dinyatakan, menggabungkan fakta dan contoh dalam kehidupan sehari-hari, mengaplikasikan konsep (prinsipprinsip, hukum dan asas), mendefinisikan istilah-istilah dan mempertimbangkan definisi, serta merumuskan alternatif-alternatif untuk solusi permasalahan. Dengan mengorganisasikan dan mengarahkan siswa dalam pembelajaran berkelompok, siswa menjadi terbiasa memecahkan suatu masalah dengan berdiskusi bersama teman-temannya. Dari kegiatan percobaan yang dilakukan oleh siswa hingga siswa memperoleh suatu kesimpulan, maka keterampilan berpikir kritis siswa dapat berkembang. Hal ini sesuai dengan yang diungkapkan oleh Buffington (2007), bahwa keterampilan berpikir kritis dapat berkembang jika guru/instruktor mengarahkan dan secara periodik mencoba mengarahkan pembelajaran. Darmawan (2008) juga mengungkapkan bahwa kemampuan berpikir kritis akan muncul dalam diri siswa apabila selama proses belajar di dalam kelas, guru membangun pola interaksi dan komunikasi yang menekankan pada proses pengetahuan secara aktif oleh siswa.

\section{Kelayakan Modul IPA Berbasis PBL untuk Meningkatkan Berpikir Kritis Siswa}

Kelayakan modul IPA berbasis PBL telah diuji melalui tahap validasi yang dlakukan oleh ahli materi, ahli bahasa, ahli media, teman sejawat (peer reviewer), dan guru IPA SMP (reviewer). Poerwadarminta (1989) menyatakan kelayakan adalah kondisi atau keadaan sudah pantas. Modul yang dikembangkan dinyatakan layak berdasarkan hasil validasi ahli materi meliputi: kesesuaian materi dengan Kompetensi Dasar (KD), kebermaknaan dan kemutahiran materi, kejelasan uraian materi, dan kedalaman materi; validasi ahli bahasa meliputi: penggunaan kata yang sesuai EYD, kesesuaian bahasa dengan tingkat perkembangan siswa SMP/MTs, komunikatif, penggunaan tanda baca, serta konsistensi penggunaan istilah, simbol dan nama ilmiah/bahasa asing; validasi ahli media meliputi: warna dan ukuran font, layout, penyajian, serta ilustrasi gambar; validasi peer reviewer dan reviewer meliputi komponen materi, 
bahasa, serta tampilan dan gambar. Berdasarkan hasil validasi dan dianalisis menggunakan cut off score, modul dinyatakan layak dengan persentase keidealan sebesar 92,0 \%.

Selain hasil validasi, kelayakan modul modul IPA berbasis PBL juga didukung oleh hasil angket respon oleh siswa dalam uji coba terbatas dan respon guru dalam tahap penyebaran modul. Dalam uji coba terbatas, diperoleh persentase keidealan sebesar 85,7 \% lebih besar daripada nilai cut off score yang mempunyai nilai $84,6 \%$. Hal ini menunjukkan bahwa modul dikategorikan layak digunakan. Sedangkan dalam penyebaran modul, guru merespons baik dengan persentase keidealan sebesar 88,2\% yang termasuk dalam kategori sangat baik. Menurut Winarno (2014) hasil respon guru pada kategori sangat baik menunjukkan bahwa modul dikategorikan layak untuk digunakan sebagai salah satu media pembelajaran.

Berdasarkan hasil validasi oleh ahli materi, ahli media, ahli bahasa, guru IPA dan peer reviewer, yang selanjutnya dilakukan perhitungan menggunakan Cut Off. Berdasarkan penghitungan, diperoleh nilai rata-rata penilaian lebih dari nilai Cut Off sehingga dapat disimpulkan bahwa modul IPA berbasis PBL pada materi suhu dan pemuaian layak digunakan. Berdasarkan hasil penelitian yang dilakukan oleh Husniyati (2016) menunjukkan bahwa modul berbasis PBL disertai diagram pohon pada materi Fotosintesis layak digunakan sebagai bahan ajar, dan berada pada kriteria sangat baik. Selain itu, pembelajaran menggunakan modul berbasis PBL disertai diagram pohon pada materi Fotosintesis dapat meningkatkan hasil belajar siswa dengan kriteria gain ternormalisasi sedang. Aryani (2015) menunjukkan bahwa terdapat perbedaan signifikan antara hasil belajar fisika siswa sebelum penerapan modul PBL dan setelah penerapan modul PBL. Hal ini dikarenakan dengan menggunakan model PBL, siswa dapat mengonstruksi pengetahuan berdasarkan pengalaman nyata, sehingga siswa akan lebih paham dengan konsep yang telah dipelajari.

\section{Kesimpulan dan Rekomendasi}

Kesimpulan dari penelitian ini adalah: 1) tahapan pembelajaran yang digunakan pada modul mengacu pada model PBL, yaitu orientasi pada masalah, mengorganisasikan siswa belajar, membimbing penyelidikan, menyajikan hasil karya, menganalisis dan mengevaluasi proses pemecahan masalah.. Aspek berpikir kritis yang ditingkatkan dengan indikator memberikan penjelasan sederhana, membangun keterampilan dasar, menyimpulkan, memberikan penjelasan lanjut, serta mengatur strategi dan teknik; 2) modul IPA berbasis PBL memenuhi kriteria sangat baik. Modul dinyatakan layak dari hasil keseluruhan validasi dengan persentase keidealan $92,0 \%$. Selain hasil validasi, kelayakan modul juga didukung oleh hasil respons siswa dalam uji coba terbatas, modul dinyatakan layak dengan persentase keidealan 85,7 \% dan respons guru dalam tahap penyebaran modul dikatakan layak digunakan dengan persentase keidealan $88,2 \%$;

Sumbangan ide dan saran berkaitan dengan peningkatan aktivitas belajar siswa yaitu: (1) keterampilan berpikir kritis dalam pembelajaran IPA wajib dipahami oleh guru sebagai pelaksana dan perencana kegiatan pembelajaran; (2) pemberian materi sebaiknya disesuaikan dengan tingkat dan jenis sekolah yang akan dijadikan penelitian.

\section{Daftar Pustaka}

Adnyana, G. P. (2012). Keterampilan Berfikir Kritis dan Pemahaman 
Konsep Siswa Pada Model Siklus Belajar Hipotesis Deduktif, Jurnal Pendidikan dan Pengajaran, Vol 45 No 3 : 201-209.

Aryani, Ima. (2015). Pengembangan Modul Problem Based Learning (PBL) pada Materi Populasi Hewan untuk Meningkatkan Kemampuan Berpikir Kreatif Mahasiswa Pendidikan Biologi Universitas Sebelas Maret. Jurnal Inkuiri. ISSN: 2252-7893, Vol 4, No. 3, 2015 (hal 68-77).

Bransford, J.D.dan Donovan, M.S. (2005). How Students Learn: Mathematics in the Classroom. Washington DC: National Academy Press.

Buffington, Melanie L. (2002). Contemporary Approaches to Critical Thinking and The World Wide Web. Journal arteducation. Vol.72 (43). Virginia commonwealth University.

Darmawan, N. H. (2008). Analisis Kemampuan Berpikir Kritis Siswa dalam Pembelajaran Berbasis Masalah pada Konsep Pencemaran Lingkungan. Jurnal Universitas Pendidikan Indonesia.

Daryanto. (2013). Menyusun Modul Bahan Ajar untuk Persiapan Guru dalam Mengajar. Yogyakarta: Gavamedia

Husniyati, Afrida. (2016). Pengembangan Modul Berbasis Problem Based Learning (PBL) disertai Diagram Pohon pada Materi Fotosintesis Kelas VIII SMP Negeri 1 Sawoo. Jurnal Inkuiri. ISSN: 2252-7893, Vol 5, No. 2, 2016 (hal 30-39).

Meltzer, D.E. (2002). The Relationship between Mathematics Preparation and Conceptual Learning Gains in Physics: A Possible "Hidden Variable" in Diagnostic Pretest Scores. American Journal of Physics. 70 (2).

Poerwadarminta. (1989). Kamus Besar Bahasa Indonesia. Balai Pustaka : Jakarta.

Polanco, R. (2004). Effects of a problembased learning program on engineering students' academic achievements in a Mexican university. Innovations in Education and Teaching International 41 (2) : 145-155.

Rubi, A. P. (2012). Penerapan Model Pembelajaran Berbasis Masalah (Problem Based Learning) untuk Meningkatkan Prestasi Belajar Siswa pada Mata Diklat Praktik Dasar Instalasi Listrik di SMK Muhammadiyah 3 Yogyakarta. Abstrak Hasil Penelitian IKIP Yogyakarta. Yogyakarta: Lembaga Penelitian.

Schafersman, S.D. (1991). An Introduction to Critical Thinking. Diakses lewat http://www.freeinquiry.com/critical -thinking.html.

Thiagarajan, Sivasailam, Dkk. (1974). Instructional Development For Training Teachers of Exeptional Children. Minesota : Indiana University.

Trianto. (2009). Mendesain Model Pembelajaran Inovativ Progresif. Jakarta: Kencana Prenada Media Group.

Winarno. (2014). Pengembangan Modul IPA Terpadu Berbasis High Order Thinking Skill (HOTS) pada Tema Energi. Tesis. Surakarta: Universitas Sebelas Maret.

Winnie, Septiani. (2009). Pendekatan Kombinasi Metode AHP Dan Metode Cut Off Point Pada Tahap Analisis Keputusan Perancangan Sistem Informasi Penjualan. PT.X. JATI UNDIP, IV (3). pp. 218-227. ISSN 1907 - 1434 